\title{
Scanning Kelvin probe analysis of the potential distribution under small drops of electrolyte
}

\author{
Rasterkelvinsondenanalyse der Potentialverteilung unter kleinen Elektrolyttropfen
}

\author{
C. Chen, C. B. Breslin and F. Mansfeld*
}

\begin{abstract}
The scanning Kelvin probe has been used to map the potential distribution under small drops of $\mathrm{NaCl}$ p!aced on carbon steel, galvanized steel, stainless steel and an aluminum alloy. The concentration of $\mathrm{NaCl}$ has been varied and the effect of chromate as inhibitor has been evaluated. In the absence of chromate local anodes and cathodes were established in a short time. For carbon steel similar potential profiles were observed in $\mathrm{NaCl}$ and $\mathrm{NaClO}_{4}$. However for stainless steel a much larger potential decrease in the center of the drop occurred in $0.5 \mathrm{~N} \mathrm{NaCl}$ than in $0.5 \mathrm{~N} \mathrm{NaClO}_{4}$ and a marked effect of chloride concentration was observed. When dichromate was added to $\mathrm{NaCl}$ a very uniform potential distribution was found for stainless steel and $\mathrm{Al} 2024$. The main driving force for development of local anodes arises from oxygen reduction in very thin films of electrolyte surrounding the $\mathrm{NaCl}$ drop.
\end{abstract}

Die Rasterkelvinsonde wurde eingesetzt, um die Potentialverteilung unter kleinen NaCl-Tropfen auf unlegiertem Stahl, verzinktem Stahl, nichtrostendem Stahl sowie einer Aluminiumlegierung aufzunehmen. Die Konzentration an $\mathrm{NaCl}$ wurde variiert und der Einfluß von Chromat als Inhibitor wurde bewertet. Bei Abwesenheit von Chromat bildeten sich innerhalb kurzer Zeit lokale Anoden und Kathoden. Für unlegierten Stahl wurden ähnliche Potentialprofile in $\mathrm{NaCl}$ und $\mathrm{NaClO}_{4}$ beobachtet. Für nichtrostenden Stahl trat jedoch in der Tropfenmitte in $0,5 \mathrm{~N} \mathrm{NaCl}$ ein wesentlich größerer Potentialabfall als in $0,5 \mathrm{NaClO}_{4}$ auf, und es wurde ein deutlicher Einfluß der Chloridkonzentration beobachtet. Bei Zugabe von Chromat zur NaCl-Lösung wurde für nichtrostenden Stahl und Al2024 eine sehr gleichmäßige Potentialverteilung gefunden. Die Haupttriebkraft für die Entwicklung lokaler Anoden ist die Sauerstoffreduktion in den sehr dünnen Elektrolytfilmen, die den $\mathrm{NaCl}-$ Tropfen umgeben.

\section{Introduction}

The Kelvin probe technique has long been used for measuring the work function and surface potential of metals and alloys in surface physics [1,2]. Recently Stratmann and coworkers have adapted this technique to determine the electrochemical behavior of corroding metals in humid gaseous environments [3-11]. The scanning Kelvin probe (SKP) can be used to measure electrode potential profiles on metallic substrates with high local resolution without touching the surface under investigation. Its non-destructive nature and the fact that it does not require electrolyte between the reference and working electrodes make it suitable for many applications such as evaluation of the kinetics of corrosion reactions of metallic substrates covered by organic coatings [8] and atmospheric corrosion phenomena [3-5], where corrosion occurs under very thin layers of moisture.

Stratmann et al. have recently reviewed their results of studies of atmospheric corrosion, delamination of organic coatings and evaluation of the properties of monomolecular adhesion

\footnotetext{
* F. Mansfeld, C. Chen

Corrosion and Environmental Effects Laboratory (CEEL) Department of Materials Science and Engineering. University of Southern California

Los Angeles, CA 90089-0241 (USA)

C. B. Breslin

Dept. Chemistry, National University of Ireland

Maynooth, Co. Kildare (Ireland)
}

promoters and ultrathin polymeric primers [12]. In the area of atmospheric corrosion the changes of $\mathrm{E}_{\mathrm{corr}}$ observed during wet/dry transitions have allowed to understand the passivation mechanism of reactive metals during drying of thin electrolyte layers. The stability of polymer coated metals and their degradation due to interaction with corrosive environments has been studied extensively by Stratmann and coworkers. Formation of galvanic elements in the presence of defects penetrating the coating could be studied in detail as a function of exposure time by taking advantage of the non-destructive nature of scanning Kelvin probe analysis (SKPA). Previously it had not been possible to determine the rate of delamination in a non-destructive manner. The stability of ultrathin polymeric films was found to be determined by the same factors as the stability of bulk coatings which allows the evaluation of new approaches for the optimization of such films as adhesion promoters [12].

In this paper results obtained using the scanning Kelvin probe to map the potential distribution under drops of electrolyte applied to metallic surfaces are presented and discussed. The scanning Kelvin probe technique has been used to determine the potential distribution under small drops of electrolyte as in the classic Evans drop experiment [13] in which the establishment of local anodes and cathodes has been derived from color changes of $\mathrm{Fe}^{2+}$ and $\mathrm{pH}$ indicators, respectively. Similar experiments have been carried out for galvanized steel, stainless steel and Al2024 in an attempt to evaluate the initial stages of localized corrosion. The effects of dichromate as inhibitor and the effects of chloride concentration on initiation of local anodes and cathodes of stainless steel have been studied [14]. 


\section{Experimental approach}

The scanning Kelvin probe was used to map the potential distribution in the classic Evans drop experiment [13] and similar drop experiments have been performed on carbon steel, galvanized steel, stainless steel (SS) type 316 and $\mathrm{Al} 2024$. Drops of different $\mathrm{NaCl}$ concentration $(0.5 \mathrm{~N}$, $0.05 \mathrm{~N}$ and $0.005 \mathrm{~N}$ ) solutions with and without potassium ferricyanide and phenolphthalein $\mathrm{pH}$ indicators were used. $\mathrm{NaCl}$ solutions containing $10 \mathrm{mM} \mathrm{Na}_{2} \mathrm{Cr}_{2} \mathrm{O}_{7}$ were also used to evaluate the inhibition effects of $\mathrm{Cr}^{6+}$. Small solution drops were applied to the metal samples using a syringe or a piece of wire.

SKPA was carried out using a commercial instrument (Corrosion Potential Measurement System, UBM Corporation, Sunnyvale, CA.). In this instrument, a $\mathrm{Cr} / \mathrm{Ni}$ needle with a diameter of about $150 \mu \mathrm{m}$ was used as the probe. The vibra- tion amplitude was approximately $20 \mu \mathrm{m}$ and the working distance between the tip and the studied surface was maintained at $50 \mu \mathrm{m}$. The vibration frequency was fixed at about $2 \mathrm{kHz}$. The scanned area was $6 \mathrm{~mm} \times 6 \mathrm{~mm}$ with the resolution of 10 points $/ \mathrm{mm}$ in the $\mathrm{x}$ direction and 5 points $/ \mathrm{mm}$ in the $y$ direction or $3 \mathrm{~mm} \times 3 \mathrm{~mm}$ with 10 points $/ \mathrm{mm}$ in both directions. The sample was mounted in the sample holder and placed in the chamber at about $100 \%$ relative humidity. For $\mathrm{Al} 2024$, to ensure good electrical contact to the needle connected to the measurement amplifier, the sample was first scratched at this contacting point to remove the insulating oxide layer. The scanning probe was then moved to the area to be analyzed and a distance calibration was made at the starting point of the area to be scanned to set the working distance between the probe and the measuring surface to a constant value of $50 \mu \mathrm{m}$. A surface profile was then measured, followed by the surface potential measurement.

\section{(a)}
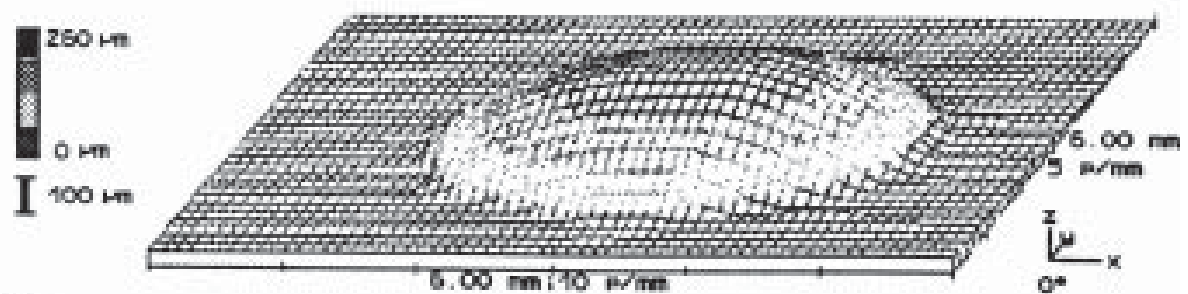

(b)

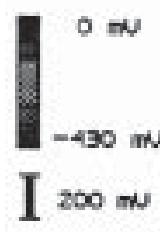

(C)

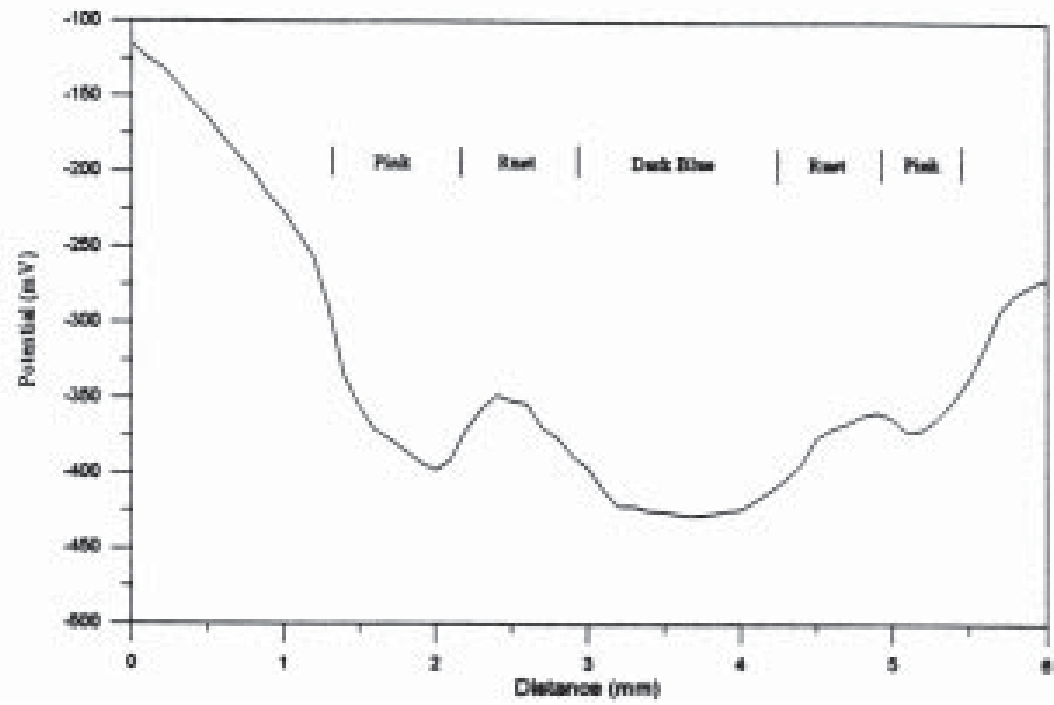

Fig. 1. Height profile (a), 3-D potential distribution (b) and 2-D potential distribution (c) for carbon steel covered by a drop of $0.05 \mathrm{~N} \mathrm{NaCl}$ containing indicators

Abb 1. Höhenprofil (a), 3-D Potentialverteilung (b) und 2-D Potentialverteilung (c) für unlegierten Stahl, der mit einem Tropfen Inhibitor enthaltener $0,05 \mathrm{~N} \mathrm{NaCl}$-Lösung bedeckt war 


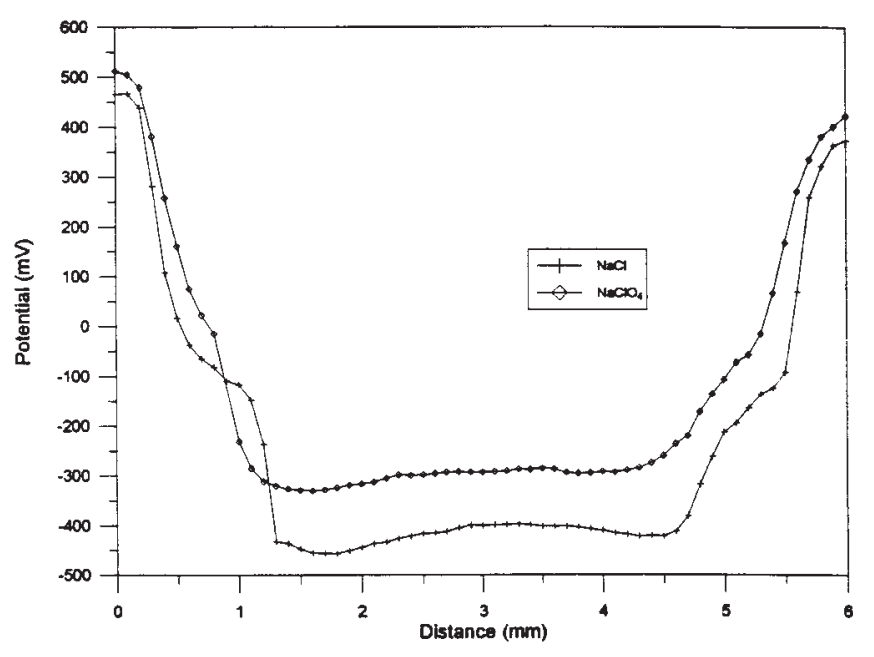

Fig. 2. 2-D potential distributions for carbon steel covered by a drop of $0.05 \mathrm{~N} \mathrm{NaCl}$ or $\mathrm{NaClO}_{4}$

Abb 2. 2-D Potentialverteilungen für unlegierten Stahl, der mit einem Tropfen $0,05 \mathrm{~N} \mathrm{NaCl}$ oder $\mathrm{NaClO}_{4}$ bedeckt war

Before each measurement, a voltage calibration was made to calibrate the Volta potential difference measured by the Kelvin probe to $\mathrm{E}_{\text {corr }}$ of the sample relative to Standard Hydrogen Electrode (SHE). A Cu/CuSO 4 electrode (a copper plate containing a cavity filled with saturated copper sulfate solution) was placed in the measurement chamber. The potential of the $\mathrm{Cu} / \mathrm{CuSO}_{4}$ electrode is $320 \mathrm{mV}$ relative to SHE. After measur- ing the Volta potential of the $\mathrm{Cu} / \mathrm{CuSO}_{4}$ electrode, a correction factor was calculated which was then added to all subsequent measured Volta potential values to provide $\mathrm{E}_{\text {corr }}$ on the SHE scale. All potentials quoted here refer to the SHE scale.

\section{Experimental results and discussion}

Similar to the classic Evans drop experiment [13], a drop of $0.05 \mathrm{~N} \mathrm{NaCl}$ containing potassium ferricyanide and phenolphthalein $\mathrm{pH}$ indicators was applied on a carbon steel sample $[14,15]$. The height profile of the drop is shown in Fig. 1a. The diameter of the drop was about $4 \mathrm{~mm}$. Fig. $1 \mathrm{~b}$ presents the potential distribution of the scanned area. The potential distribution established rings of different potentials which corresponded to the rings of different colors. The potential difference between the cathode at the edge of the drop and anode in the center of the drop was relatively small. 1t is likely that most of the driving force for the dissolution reaction in the center of the drop resulted from $\mathrm{O}_{2}$ reduction reaction in the thin electrolyte layers adjacent to the drop. Fig. 1c shows the potential distribution across the drop in two dimensions and gives information about the observed color changes in the solution. The pink colors indicated formation of $\mathrm{OH}^{-}$at cathodes due to oxygen reduction reaction and the dark blue color indicated formation of $\mathrm{Fe}^{2+}$ at the anode. Between the pink and blue zone, brown rusts formed as precipitation of $\mathrm{Fe}(\mathrm{OH})_{3}$ due to oxidation of $\mathrm{Fe}^{2+}$ to $\mathrm{Fe}^{3+}$ and diffusion of $\mathrm{Fe}^{3+}$ and $\mathrm{OH}^{-}$. A potential peak is observed in this region. The potential in the outside ring was between -250 to $-400 \mathrm{mV}$ (SHE) and dropped to about $-430 \mathrm{mV}$ in the center of the

(a)
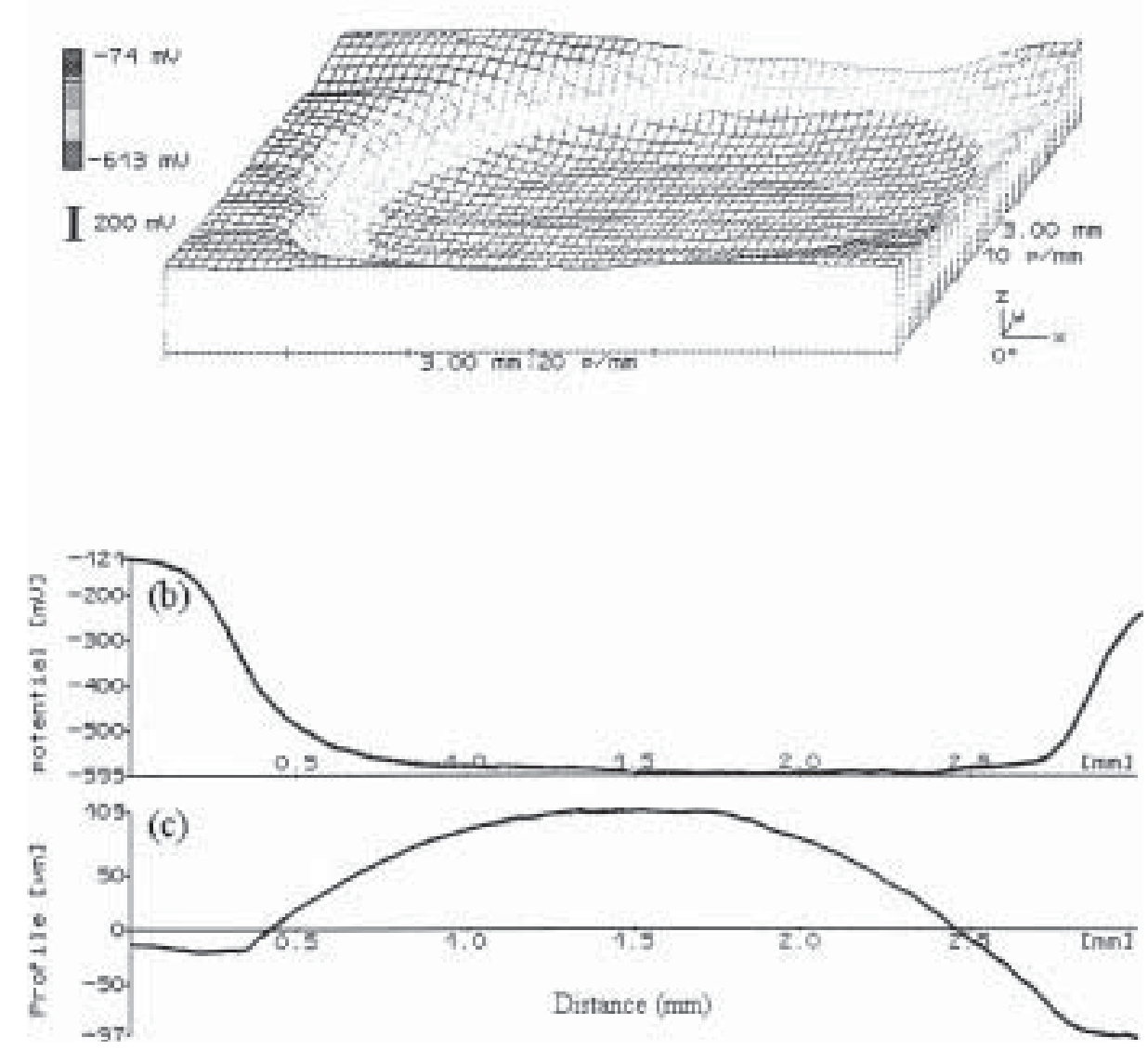

Fig. 3. 3-D potential distribution (a), 2-D potential distribution (b) and height profile (c) for galvanized steel covered by a drop of $0.5 \mathrm{~g} / \mathrm{l} \mathrm{NaCl}$ and $3.5 \mathrm{~g} / \mathrm{l}\left(\mathrm{NH}_{4}\right)_{2} \mathrm{SO}_{4}$ solution

Abb 3. 3-D Potentialverteilung (a), 2-D Potentialverteilung (b) und Höhenprofile (c) für verzinkten Stahl, der mit einem Tropfen 0,5 g/l NaCl und 3,5g/l $\left(\mathrm{NH}_{4}\right)_{2} \mathrm{SO}_{4}$-Lösung bedeckt war 
drop. The potential changed at a rate of $-117 \mathrm{mV} / \mathrm{mm}$ in the outermost region of the scanned area and at a rate of $-285 \mathrm{mV} / \mathrm{mm}$ in the region adjacent to the drop (left hand side of Fig. 1c). The potential drop outside the drop occurred in a very thin layer of moisture, where oxygen reduction is much faster than in bulk electrolyte $[16,17]$.

Another drop experiment was carried out using the $0.05 \mathrm{~N} \mathrm{NaCl}$ solution without the indicators since it was possible that these indicators changed the potential distribution. The potential distribution was very similar to that for the drop containing indicators, indicating that the presence of phenolphthalein and potassium ferricyanide indicators did not have significant effects on the potential distribution. In order to test the hypothesis that the nature of the anion had no effect in a differential cell, SKPA was also performed for a drop of $\mathrm{NaClO}_{4}$ placed on carbon steel. The potential distribution under a drop of $0.05 \mathrm{~N} \mathrm{NaClO}_{4}$ was very similar to that for $\mathrm{NaCl}$ drop showing that an aggressive anion such as $\mathrm{Cl}$ is not necessary to establish a differential aeration ceIl. Fig. 2 gives the potential distribution across the carbon steel sample for drops of $\mathrm{NaCl}$ and $\mathrm{NaClO}_{4}$. In these two experiments the drops were about $3 \mathrm{~mm}$ in diameter, smaller than the drop with indicators (Fig. 1). Due to the smaller drops, the potential of carbon steel free of any liquid, which was found to be between 460 and $520 \mathrm{mV}$ vs. SHE, was recorded at the edge of the scanned area. The greatest potential decrease occurred in the very thin layers around the drop. When the solution had dried out, the area under the drop was covered with rust and was surrounded by a discolored area.

A drop of a solution of $0.5 \mathrm{~g} / 1 \mathrm{NaCl}$ and $3.5 \mathrm{~g} / 1\left(\mathrm{NH}_{4}\right)_{2} \mathrm{SO}_{4}$ solution was placed on a galvanized steel sample to simulate atmosphere corrosion processes. The three-dimensional potential distribution under the drop is shown in Fig. 3a. A two-dimensional plot for the potential and a height profile is shown in Fig. 3b and Fig. 3c. There was a very sharp potential difference of about $470 \mathrm{mV}$ between outside the drop and the center of the drop. The potential decreased the fastest at the edge of the drop and was relatively constant in the center. The constant potential distribution under the drop was different from that observed on carbon steel (Fig. 1 and Fig. 3), where a potential ring between the anode and the cathode corresponding to rust formation was evident. For galvanized steel there was no accumulation of corrosion products as the corrosion species $\mathrm{ZnO}_{4}^{2-}$ are soluble.

Fig. 4a presents the potential distribution for Al 2024 covered by a drop of $0.5 \mathrm{~N} \mathrm{NaCl}$ solution. Under the $\mathrm{NaCl}$ drop the potentials were lower than those at surrounding areas and a potential minimum occurred at the center of the drop. The potential distribution for $\mathrm{Al} 2024$ covered by a drop of $0.5 \mathrm{~N} \mathrm{NaCl}$ containing $10 \mathrm{mM} \mathrm{Na}_{2} \mathrm{Cr}_{2} \mathrm{O}_{7}$ was very smooth without a potential decrease under the drop (Fig. 4b). The presence of $\mathrm{Cr}^{6+}$ in the solution inhibited dissolution of $\mathrm{Al}$ and therefore prevented formation of local anodes and cathodes.

The potential distribution for a SS 316 sample scanned in humid air is shown in Fig. 5a. The potentials were very positive in the range of 565 to $595 \mathrm{mV}$. A drop of $0.5 \mathrm{~N} \mathrm{NaCl}$ produced a very different potential distribution (Fig. 5b). The potentials under the drop were much more negative than in the area surrounding the drop. The lowest potential occurred in the center of the drop and the potential difference between the center and outside the drop was as high as

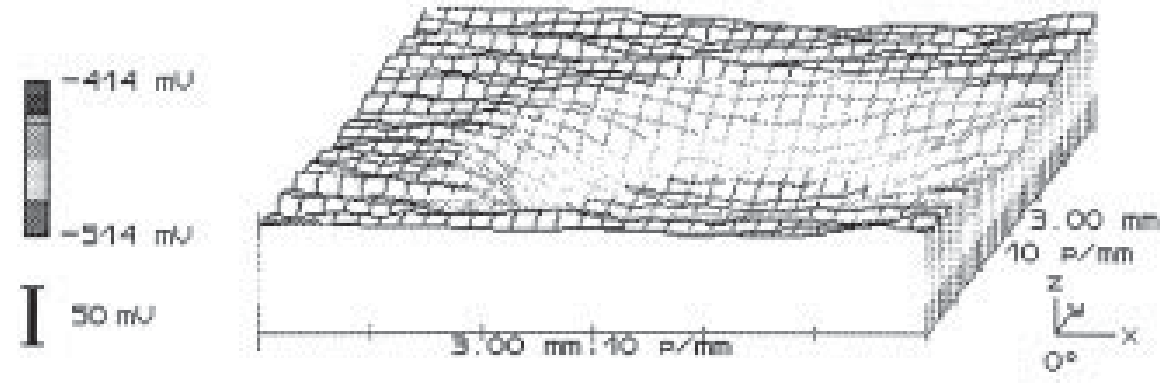

(b)

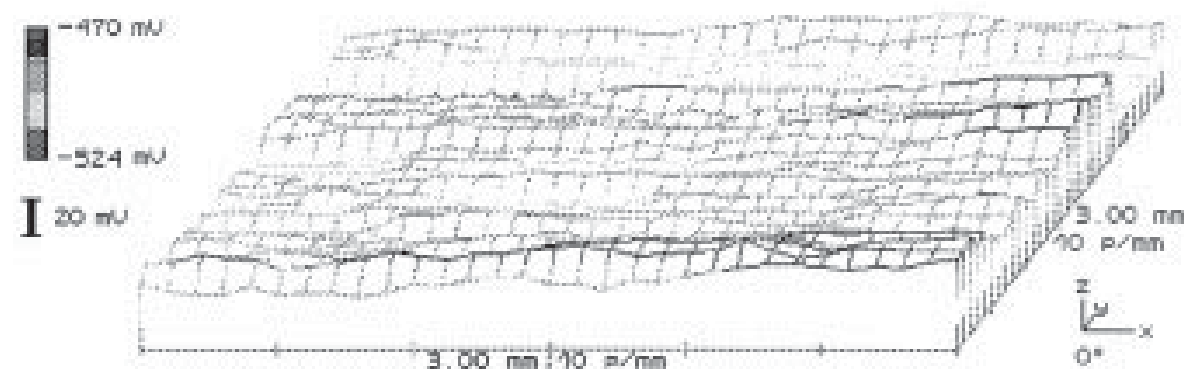

Fig. 4. Potential distributions for $\mathrm{Al} 2024$ covered by a drop of $0.5 \mathrm{~N} \mathrm{NaCl}$ (a) and a drop of $0.5 \mathrm{~N} \mathrm{NaCl}$ containing $10 \mathrm{mM} \mathrm{Na}_{2} \mathrm{Cr}_{2} \mathrm{O}_{7}$ (b)

Abb 4. Potentialverteilungen für Al2024, das mit einem Tropfen 0,5 N NaCl Lösung (a) bzw. mit einem Tropfen $10 \mathrm{mM} \mathrm{Na} \mathrm{Cr}_{2} \mathrm{O}_{7}$ enthaltener 0,5 N NaCl-Lösung (b) bedeckt war 
(a)

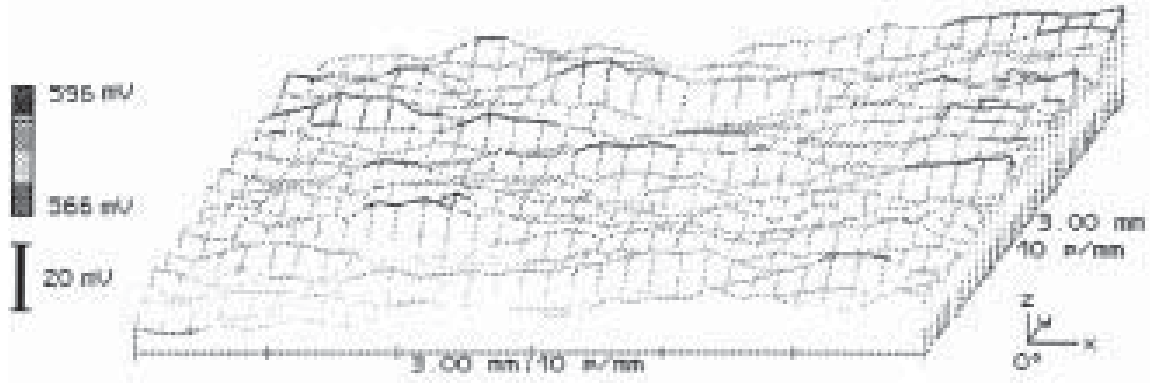

(b)
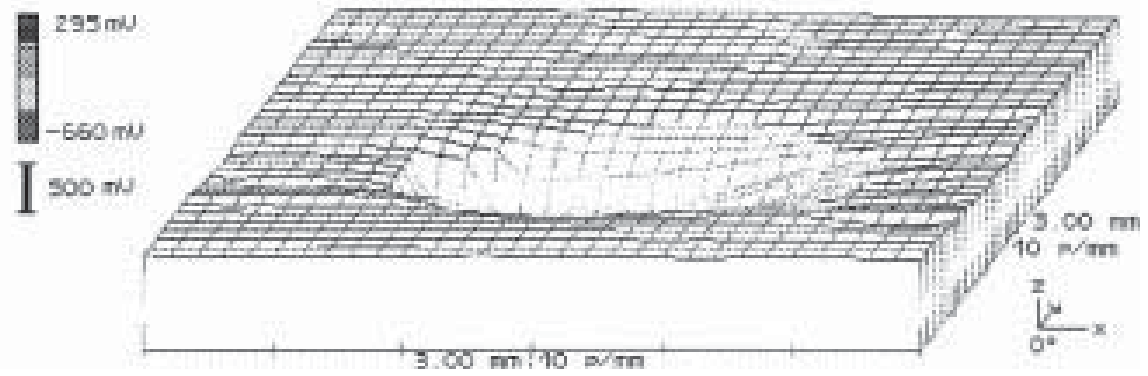

Fig. 5. Potential distributions for SS 316 without solution (a) and SS 316 covered by a drop of $0.5 \mathrm{~N} \mathrm{NaCl}$ (b)

Abb 5. Potentialverteilungen für SS 316 ohne Lösung (a) und für SS 316 , der mit einem Tropfen $0,5 \mathrm{~N} \mathrm{NaCl}$ (b) bedeckt war
$950 \mathrm{mV}$ suggesting that the passive film had broken down locally due to pit formation. Compared with the positive potentials in Fig. 5a, the potentials outside the $0.5 \mathrm{~N} \mathrm{NaCl}$ drop were much lower most likely due to a very thin layer of moisture surrounding the drop in which oxygen reduction reaction occurred. The measurement in Fig. 5a was made after the drop was on the sample for about 30 minutes. Additional measurements were carried out after 2 hours and 18 hours. Very similar potential distributions were obtained. Two-dimensional plots for the height profiles and potential distributions across the sample at the center of the drop are shown in Fig. 6a and Fig. 6b. The height profile did not change much with time. However, the potential minimum under the drop became more positive with time. This potential difference decrease with exposure time indicated that the driving force for Fe dissolution and therefore the pit growth rate decreased with exposure time.

The potential distribution on SS 316 covered by drops of $0.05 \mathrm{~N} \mathrm{NaCl}$ or $0.005 \mathrm{~N} \mathrm{NaCl}$ for about 30 minutes had similar shapes to those observed for $0.5 \mathrm{~N} \mathrm{NaCl}$. However, the potentials outside the drop were higher with values of about $580 \mathrm{mV}$, which were close to the potential values for SS 316 without a drop. Two-dimensional plots for the potential distribution are shown in Fig. 7. For $0.5 \mathrm{~N} \mathrm{NaCl}$, the potential distribution had the shape of a deep pit. For $0.05 \mathrm{~N} \mathrm{NaCl}$ or $0.005 \mathrm{~N} \mathrm{NaCl}$, the potentials under the drop were much high- er than those for $0.5 \mathrm{~N} \mathrm{NaCl}$. The potentials outside the $0.05 \mathrm{~N}$ or $0.005 \mathrm{~N} \mathrm{NaCl}$ drops had values similar to those for SS 316 without any solution. The potential difference between the outside of the drop ( $2.5 \mathrm{~mm}$ from the drop center) and the drop center decreased when the $\mathrm{Cl}^{-}$concentration decreased (Fig. 8). Higher $\mathrm{Cl}^{-}$concentration produced a higher potential difference between the anode and the cathode areas and therefore provided a larger driving force for passive film breakdown and $\mathrm{Fe}$ dissolution. In the $\log$ potential difference $\Delta \mathrm{E}-\log \mathrm{Cl}^{-}$concentration plot of Fig. 8, the experimental data could be fit to a straight line with a slope of 0.5 indicating that $\Delta \mathrm{E}$ increased with the square root of the $\mathrm{Cl}^{-}$concentration. When a small drop of $0.5 \mathrm{~N} \mathrm{NaClO}_{4}$ was placed on the SS 316 surface a much smaller potential difference $\Delta \mathrm{E}$ was observed suggesting that the large $\Delta \mathrm{E}$ values found for $\mathrm{NaCl}$ were due to the aggressive nature of $\mathrm{Cl}^{-}$(Fig.9).

A drop of $0.5 \mathrm{~N} \mathrm{NaCl}$ containing $10 \mathrm{mM} \mathrm{Na}_{2} \mathrm{Cr}_{2} \mathrm{O}_{7}$ placed on SS 316 gave a totally different potential distribution (Fig. 10) than for $0.5 \mathrm{~N} \mathrm{NaCl}$. There was no potential decrease under the drop. From the potential distribution it was impossible to determine where the drop had been placed. The potential distribution was similar to that for SS 316 without a drop of solution because of the inhibitive effect of $\mathrm{Cr}^{6+}$ which prevented localized breakdown of the passive film. 

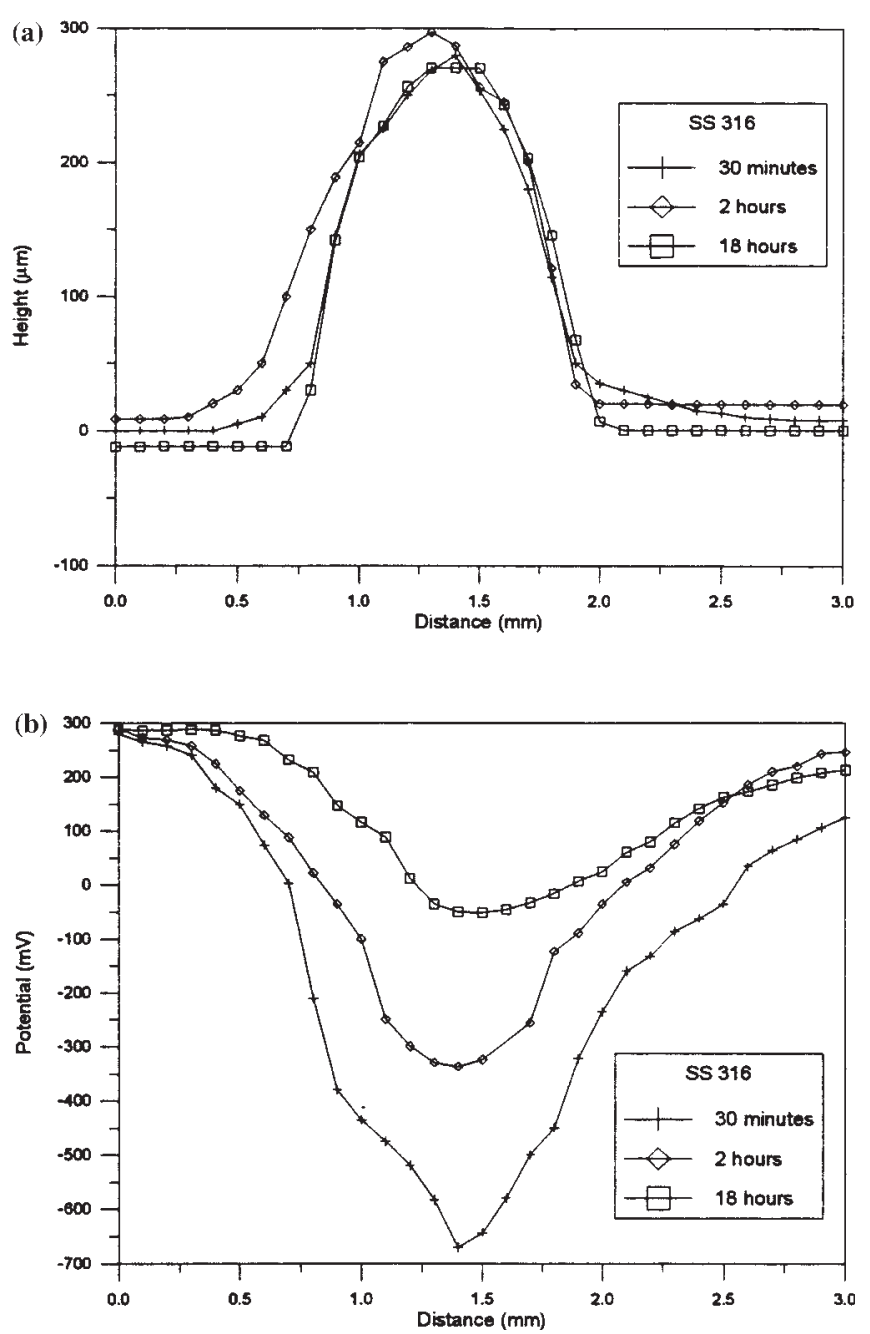

Fig. 6. Height profile (a) and 2-D potential distribution (b) across SS 316 at the center of $0.5 \mathrm{~N} \mathrm{NaCl}$ drop as a function of exposure time

Abb 6. Höhenprofil (a) und 2-D Potentialverteilungen (b) durch das Zentrum eines 0,5 N NaCl-Tropfens auf SS 316 als Funktion der Auslagerungszeit

\section{Summary and conclusions}

The potential distribution occurring in the classic Evans drop experiment has been determined using the scanning Kelvin probe. Different potential regions corresponding to the dissolution of iron in the center of the drop, the region where a rust ring is formed, and the cathodic region at the edge of the drop have been determined. The largest driving force for for-

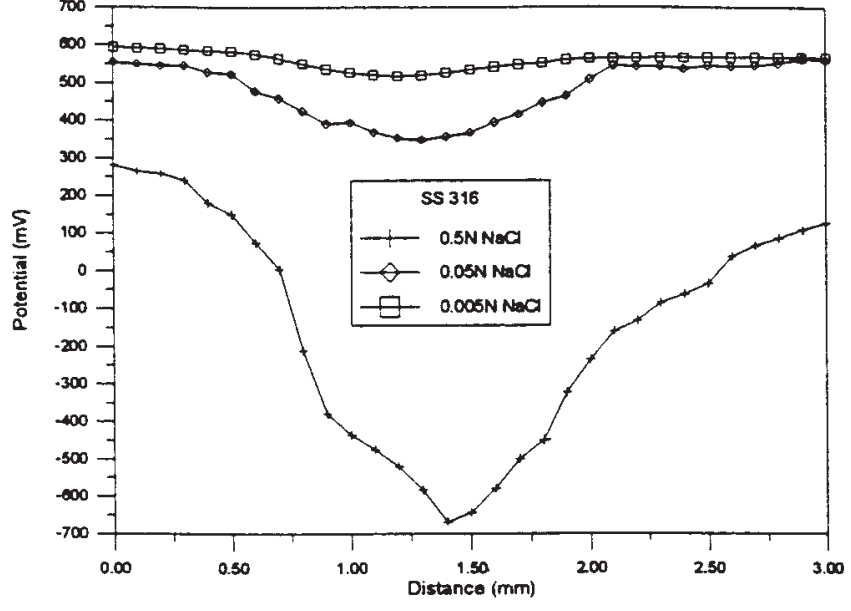

Fig. 7. Potential distribution across SS 316 at the center of $\mathrm{NaCl}$ drops as a function of $\mathrm{Cl}^{-}$concentration

Abb 7. Potentialverteilungen durch das Zentrum eines $0,5 \mathrm{~N} \mathrm{NaCl}$ Tropfens auf SS 316 als Funktion der $\mathrm{Cl}^{-}$-Konzentration

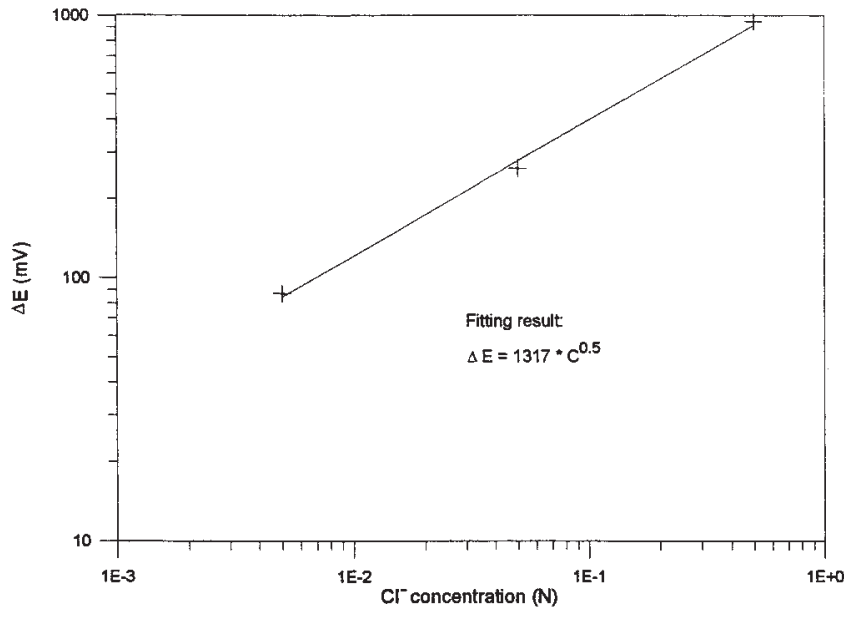

Fig. 8. Potential difference $\Delta \mathrm{E}$ between the area outside the drop and the center of the drop on SS 316 as a function of $\mathrm{Cl}^{-}$concentration

Abb 8. Potentialdifferenz $\Delta \mathrm{E}$ zwischen dem Bereich außerhalb des Tropfens und dem Tropfenzentrum auf SS 316 als Funktion der $\mathrm{Cl}^{-}$-Konzentration

mation of local cathodes arises from oxygen reduction in the regions inside and outside of the drop close to its edge. Very similar results were obtained for solutions containing $\mathrm{Cl}^{-}$and $\mathrm{ClO}_{4}^{-}$showing that the nature of the anion does not play a role

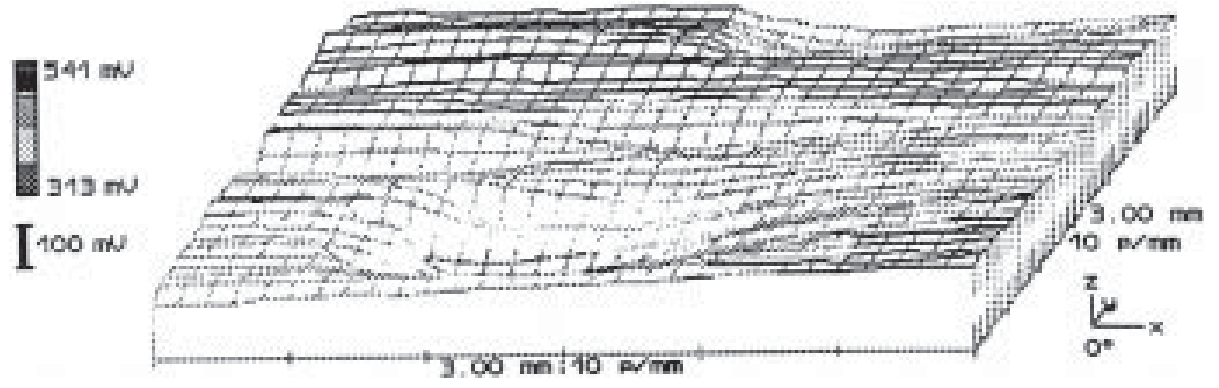

Fig. 9. Potential distribution for SS 316 covered by a drop of $0.5 \mathrm{~N} \mathrm{NaClO}_{4}$

Abb. 9. Potentialverteilung für SS 316, der mit einem Tropfen $0,5 \mathrm{~N} \mathrm{NaClO}_{4}$-Lösung bedeckt war 


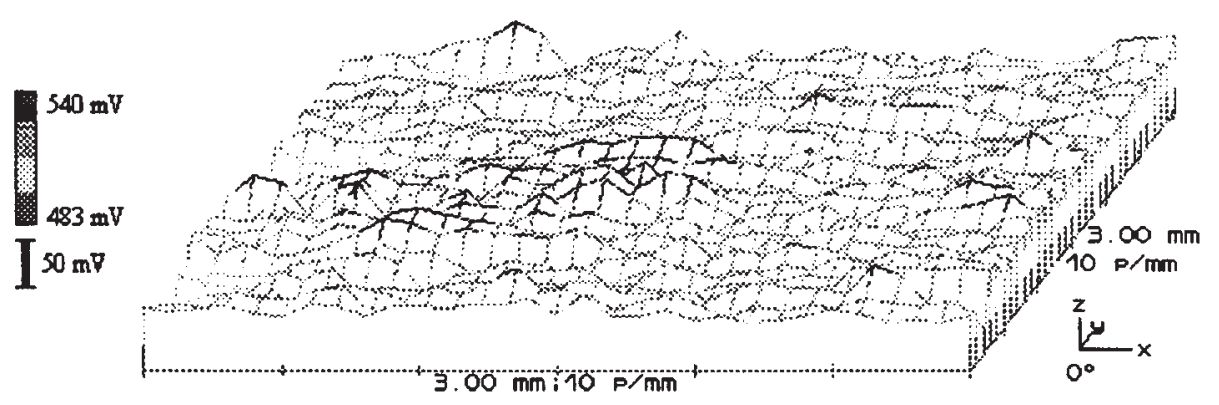

Fig. 10. Potential distribution for SS 316 covered by a drop of $0.5 \mathrm{~N} \mathrm{NaCl}$ containing $10 \mathrm{mM} \mathrm{Na}_{2} \mathrm{Cr}_{2} \mathrm{O}_{7}$

Abb. 10. Potentialverteilung für SS 316, der mit einem Tropfen $10 \mathrm{mM} \mathrm{Na}_{2} \mathrm{Cr}_{2} \mathrm{O}_{7}$ enthaltener $0,5 \mathrm{~N}$ NaCl-Lösung bedeckt war in the establishment of local anodes and cathodes on carbon steel. The results for galvanized steel differed from those for carbon steel insofar as a constant potential region was found under the drop which meant that most of the surface was actively dissolving while oxygen reduction occurred in a narrow region on both sides of the edges of the drop. For Al 2024 the inhibitive action of dichromate was quite evident. No potential decrease such as that observed in $\mathrm{NaCl}$ without dichromate was found.

For stainless steel type 316 the effects of exposure time, chloride concentration and additions of dichromate were investigated. Under a drop of $0.5 \mathrm{~N} \mathrm{NaCl}$ a sharp potential minimum occurred in a relatively short time. With increasing exposure time the potential difference between the outside and the center of the drop decreased. The potential difference became larger with increasing $\mathrm{Cl}^{-}$concentration. Addition of dichromate eliminated any breakdown of the passive film by $\mathrm{Cl}^{-}$as shown by the flat potential distribution across the drop. Contrary for the equivalent experiment with carbon steel a strong anion effect was observed. Under a drop of $\mathrm{NaClO}_{4}$ only a small potential decrease occurred.

The results presented here suggest that the use of the scanning Kelvin probe can be extended to other areas than those studied so far. lt has been shown previously that SKPA is a valuable non-destructive tool for the evaluation of the efficiency of various passivation treatments for welded stainless steel [18]. The experimental results presented here demonstrate that SKPA can also be used to study the initial stages of localized corrosion phenomena such as the formation of local anodes and cathodes on active metals such as carbon steel and galvanized steel, and breakdown of the passive film on stainless steel.

\section{Acknowledgement}

The authors acknowledge helpful discussions with Dr. $R$. Emmerich, UBM Corp. Ettlingen, Germany. C. B. Breslin acknowledges support from Forbairt under its International Collaboration Scheme.

\section{References}

[1] G. Ertl, J. Kuppers: Low-Energy Electrons and Surface Chemistry, Verlag Chemie, Weinheim (1974).

[2] G. L. Gaines, Jr.: Insoluble Monolayers at Liquid/Gas Interfaces, pp. 79-89, Interscience, New York (1966).

[3] M. Stratmann, H. Streckel: Corros. Sci. 30 (1990) 681.

[4] M. Stratmann, H. Streckel: Corros. Sci. 30 (1990) 697.

[5] M. Stratmann, H. Streckel: Corros. Sci. 30 (1990) 715.

[6] M. Stratmann: Ber. Bunsenges. Phys. Chem. 94 (1990) 626.

[7] S. Yee, R. A. Oriani, M. Stratmann: J. Electrochem. Soc. 138 (1991) 55.

[8] M. Stratmann, M. Wolpers, H. Streckel, R. Feser: Ber. Bunsenges. Phys. Chem. 95 (1991) 1365.

[9] M. Stratmann, H. Streckel: Werkst. Korros. 43 (1992) 316.

[10] A. Leng, M. Stratmann: Corros. Sci. 34 (1993) 1657.

[11] M. Stratmann, R. Feser, A. Leng: Electrochimica Acta 39 (1994) 1207.

[12] M. Stratmann, W. Fuerbeth, G. Grundmeier: Proc. Corrosion/ 97, Research Topical Symp., p. 1 (1997), NACE.

[13] U. R. Evans: Metal Ind. 29 (1926) 481.

[14] C. Chen: Ph. D. thesis, Univ. Southern California, August 1997.

[15] C. Chen, F. Mansfeld: Corr. Sci. 39 (1997) 409

[16] F. Mansfeld, S. Tsai: Corr. Sci. 20 (1980) 853.

[17] F. Mansfeld: New Approaches to Atmospheric Corrosion Research Using Electrochemical Techniques, in Corrosion Processes, R. N. Parkins, ed., Appl. Sci. Publ., London, 1982, p 1.

[18] L. T. Han, F. Mansfeld: Corr. Sci. 39 (1997) 199.

(Received: October 6, 1997)

W 3234 